\title{
Modelling the dispersion of benzene emissions from a proposed ethanol producing facility in Farewell-Oshawa of Toronto, Canada
}

\author{
Abdul-Wahab S.A. ${ }^{1,2,}{ }^{*}$, En S.C.F. ${ }^{2}$, Jaffeer H. ${ }^{2}$, Elkamel A. ${ }^{2}$, Yetilmezsoy K. ${ }^{3}$ and Ahmadi L. ${ }^{2}$ \\ ${ }^{1}$ Department of Mechanical and Industrial Engineering, Sultan Qaboos University, P.O Box 33, PC 123, Muscat, Oman \\ 2Department of Chemical Engineering, University of Waterloo, N2L 3G1, Waterloo, Ontario, Canada \\ ${ }^{3}$ Department of Environmental Engineering, Faculty of Civil Engineering, Yildiz Technical University, 34220, Davutpasa, Esenler, Istanbul, \\ Turkey \\ Received: 30/12/2015, Accepted: 07/09/2017, Available online: 25/09/2017 \\ *to whom all correspondence should be addressed: \\ e-mail: sabah1@squ.edu.om; s2alsula@uwaterloo.ca
}

\section{Abstract}

The production and use of biofuels such as ethanol have been the target of intensive research. One source of ethanol is corn, which is abundant in many countries. In producing ethanol from corn, an assessment of the environmental impact of the process is needed. This study intends to provide insight into benzene emitted from a proposed biofuel plant, its dispersion behavior, and the effects it may have on the immediate environment. Threeseason (January, April, and June) dispersion results of benzene emissions from the proposed ethanol-producing facility are evaluated by using the CALPUFF modelling system. Within the framework of the CALPro software, ambient benzene concentrations are modelled over a 24hour period of exposure by considering the impact of pollutant transformation and removal, and meteorological factors such as wind direction and speed, and temperature. Simulations are performed for the plant area located in Farewell, Oshawa, Ontario, based on the emission and meteorological dataset for the year 2013. The modeling domain covers the area of $30 \times 30 \mathrm{~km}^{2}$ with the grid spacing of $150 \mathrm{~m}$. The number of grid lines is taken as 200 for each axis, and the dispersion of benzene emissions is simulated in nine vertical layers of the domain of study. Based on simulated one-hour and 24-hour average benzene concentrations, pollution dispersion results show that the maximum concentrations are recorded as 4.585 and $0.403 \mu \mathrm{g} / \mathrm{m}^{3}$ at $17 \mathrm{~h} 00$ LST on hourly basis and on 24hour basis, respectively, for the winter season. For the spring season, the highest concentrations are measured as 1.345 and $0.136 \mu \mathrm{g} / \mathrm{m}^{3}$ at $21 \mathrm{~h} 00$ LST for one-hour and 24hour periods, respectively. For the summer season, the peak benzene concentrations are found to be 1.085 and $0.277 \mu \mathrm{g} / \mathrm{m}^{3}$ at $01 \mathrm{hOO} \mathrm{LST}$. The results indicate that none of the months exceeds the half-hour limit of $7 \mu \mathrm{g} / \mathrm{m}^{3}$ set by Ontario Regulation 419/05, but they surpass the Ontario Regulation 419 Schedule 3 limit of $0.01 \mu \mathrm{g} / \mathrm{m}^{3}$ for a 24-hour dispersion period. This information may prove invaluable to further research on the impacts of the ethanolproduction process on the environment.
Keywords: Benzene; corn; dispersion; ethanol producing facility; modelling

\section{Introduction}

Benzene $\left(\mathrm{C}_{6} \mathrm{H}_{6}\right)$ is an aromatic hydrocarbon, with a sweet aroma; however, it is also a recognized class 1 human carcinogen (Alexopoulos and Bakeas, 2011; Benigni et al., 2013). Acute exposure to benzene via inhalation can cause symptoms such as dizziness and confusion. At high exposures, the vapour affects neurological pathways. Chronic exposure to benzene can result in anemia, leukopenia, and thrombocytopenia (Ellenhorn et al., 1997).

The FarmTech Energy Corporation in Canada has proposed an ethanol fuel production plant which converts corn into ethanol and distiller's grain. However, there are a number of pollutants emitted at different stages of the process, such as particulates, volatile organic compounds (VOCs), and oxides of sulfur $\left(\mathrm{SO}_{\mathrm{x}}\right)$ and nitrogen $\left(\mathrm{NO}_{\mathrm{x}}\right)$. Among the pollutants in the fugitive emissions and flares, benzene was selected for further study based on its low dose-dependent potency (Boobis et al., 2013) and because it is a significant contaminant emitted from the aforementioned plant. There are two readily available benzene concentration regulation references for comparison. The first is the Ontario Regulation 419 Schedule 3 limit of $0.01 \mu \mathrm{g} / \mathrm{m}^{3}$ for a 24-hour dispersion period. The other limit is a guideline set by Ontario Regulation 419/05 with a guideline concentration of $7 \mu \mathrm{g} / \mathrm{m}^{3}$ for a half-hour dispersion period (Government of Ontario, 2013). In previous studies, benzene surpassed its allowable 24-hour dispersion limit in AERMOD simulations, reaching a peak concentration point of $0.8 \mu \mathrm{g} / \mathrm{m}$ (800\%) (Agriculture and Agri-Food Canada, 2012).

One useful tool for dispersion modelling is California Puff (CALPUFF), an environment modelling software approved by the US Environmental Protection Agency (Holnicki et al., 2016; Abdul-Wahab et al., 2016; Abdul-Wahab et al., 2015; Abdul-Wahab et al., 2014; Abdul-Wahab et al., 2006). CALPUFF, a non-steady-state Lagragian Gaussian puff model, was chosen over other modelling software such as 
AERMOD, the Buoyant Line and Point (BLP) source dispersion model, and the third generation California Line Source Dispersion Model (CALINE3) because, unlike these models, CALPUFF does not use steady state assumptions to model plume trajectories from a point source (The Atmospheric Studies Group, 2013). Other research papers have used CALPUFF to model the ambient concentrations of benzene from other sources such as vehicle emissions (Cohen et al., 2005) and from a coke plant (Valdenebro et al., 2013). In the current study, CALPUFF was used extensively to model the ambient benzene concentrations over a 24-hour period of exposure, whilst taking into consideration the effect of pollutant transformation and removal, and meteorological factors such as wind direction and speed, and temperature. A more detailed comparison of various dispersion softwares including CALPUFF and AERMOD, can be found in Holmes and Morawska (2006).

It is particularly interesting to examine the pollutant emission concentrations of FarmTech's proposed plant because it will produce renewable energy, an emerging field of study in modern science. This study will also attempt to add to a minuscule database of dispersion information with regards to benzene emissions from an ethanol plant. As FarmTech is consistent a leader in sustainable energy and promotes a concern for the environment, in constructing an ethanol plant, it is imperative that knowledge of possible dispersion trends of benzene is acquired. Such knowledge is important not only to build a better general understanding of the associated health effects of benzene have on people, but also because the proposed plant will be located in an extensively populated area, and will be close to the port and other key industries such as agriculture.

\section{Methodology}

\subsection{Description of the study area}

The proposed location of the plant is shown in Figure 1 (latitude: $43.866667^{\circ} \mathrm{N}$, longitude: $78.816667{ }^{\circ} \mathrm{W}$ ). The plant will be in Farewell, Oshawa, Ontario, which is home to approximately 357,000 people (Statistics Canada, 2012). To the south is Lake Ontario with a deep water port accommodating the Durham Region's imports and exports (The City of Oshawa, 2012).

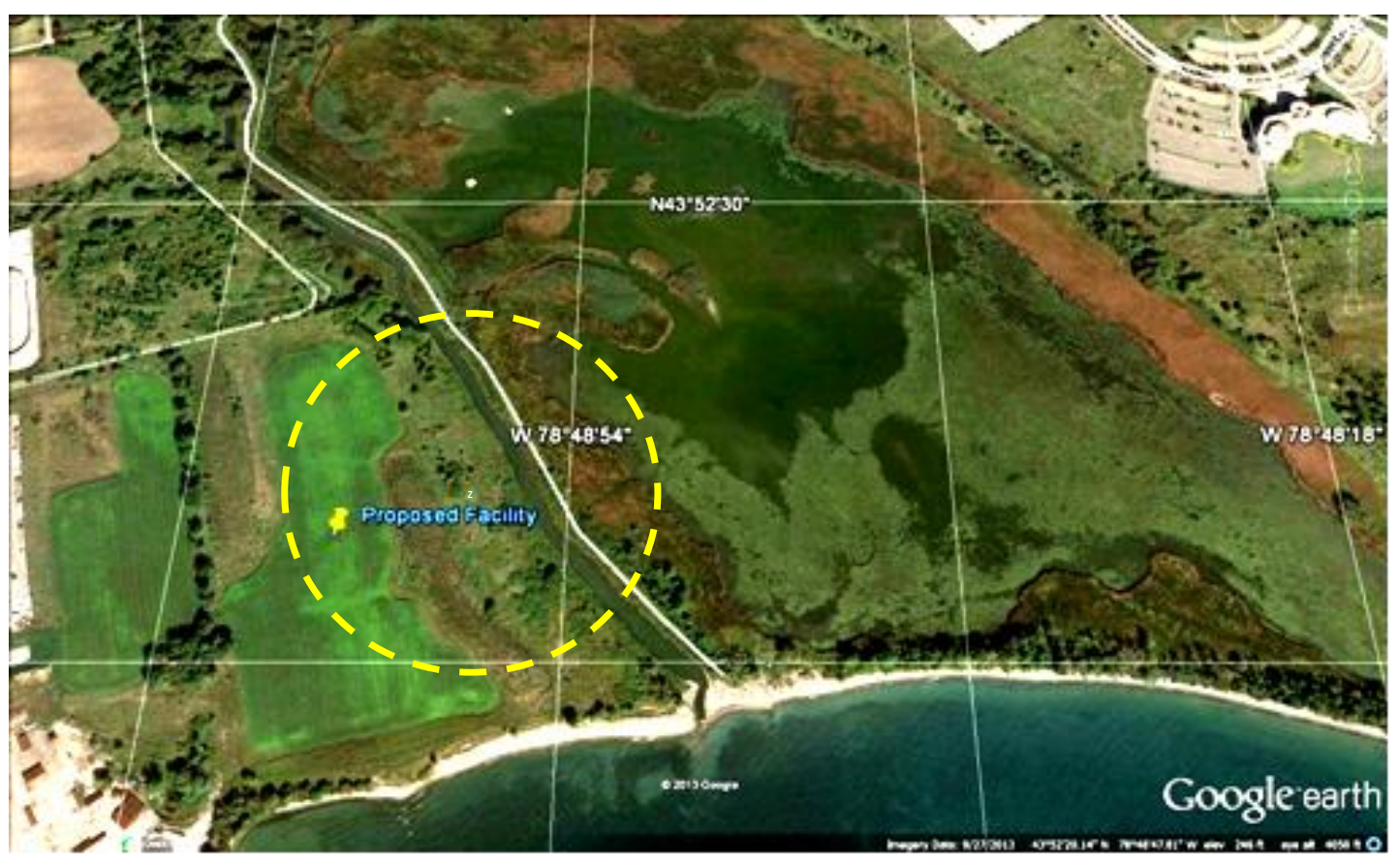

Figure 1. Satellite image showing of the location proposed plant location

Oshawa's terrain comprises mostly low-lying agricultural lands with a few kilometers of forest (Figure 2). As such, these features facilitate urbanization of the city. The city is a typical industrialized center with its key economic sectors being automotive manufacturing, sustainable energy production, and agriculture (Oshawa's Economic Development Services, 2012).

\subsection{Process of the facility}

The proposed facility's production objectives are, to produce ethanol and dried distiller's grain, a byproduct of ethanol production, from corn. Benzene emissions, however, are associated with the ethanol producing process of the plant. As such, this paper will focus on that process. The facility will introduce measures and infrastructure to reduce emissions from vital points along the process pathways, which are as follows: The dried corn will be received and sent to a mill to be ground into a coarse powder. The powder will then be added to water, and its $\mathrm{pH}$ will be raised by liquid ammonia from a separate pressurized storage location. This slurry will then be heated to reduce its viscosity and an enzyme will be added. The slurry will then be moved through a pressurized jet cooler, flash condensed, and sent to liquefaction tanks. At these liquefaction tanks, another enzyme will be added after the slurry is adjusted to its optimal temperature and $\mathrm{pH}$. This resulting mash will then be sent to a fermentation tank, where the yeast will be added. The yeast facilitates the 
conversion of the corn sugars to ethanol and carbon dioxide. After the allotted fermentation time passes, the fermented slurry will be sent to a beer well which is a pressurized apparatus responsible for facilitating a continuous feed to the distillation columns.

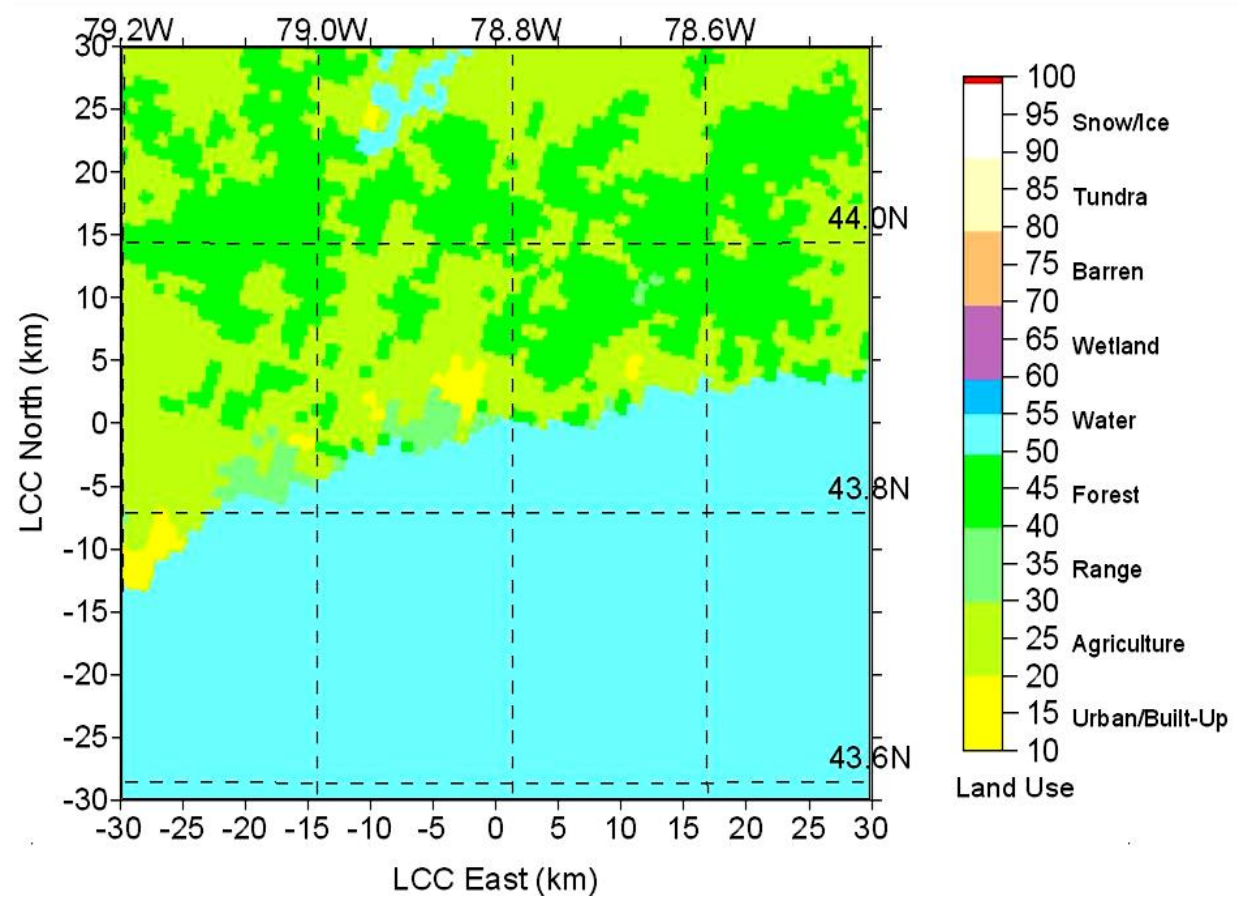

Figure 2. Land use data for the proposed plant location

The emitted air from the fermentation process will undergo gas scrubbing by a water-based scrubber to remove vestigial pollutants such as carbon dioxide and VOCs. The fermented slurry, or beer, at this point will contain $10 \%$ ethanol by volume along with other unfermented solids and water. This beer will then be sent to the distillation columns, which will separate the ethanol from those solids and the majority of the water in the mixture. The existing stream will contain $95 \%$ ethanol by volume, with the other five percent being water. This majority-ethanol mixture will then be sent to a molecular sieve to remove the remaining water, and the resulting pure ethanol will be stored in a fixed roof tank. Gasoline will then be added to this stored ethanol, making it unfit for human consumption. It should be noted that the majority of the benzene emissions from this process will escape as fugitive emissions from the tanks storing the gasoline as well as the loading of the final ethanol product (Stantec Consulting Limited, 2010). Table 1 shows all the emission sources of $\mathrm{C}_{6} \mathrm{H}_{6}$ at the ethanol producing facility.

Table 1. Input data for emission sources (Stantec Consulting Limited, 2010)

\begin{tabular}{|c|c|c|c|c|c|c|c|}
\hline ID & Source & $\begin{array}{l}\text { Source } \\
\text { type }\end{array}$ & $\begin{array}{c}\text { Stack } \\
\text { height } \\
(\mathrm{m})\end{array}$ & $\begin{array}{c}\text { Stack exit } \\
\text { temperature } \\
(\mathrm{K})\end{array}$ & $\begin{array}{c}\text { Stack exit } \\
\text { velocity } \\
(\mathrm{m} / \mathrm{s})\end{array}$ & $\begin{array}{c}\text { Stack inner } \\
\text { diameter } \\
(\mathrm{m})\end{array}$ & $\begin{array}{c}\text { Emission } \\
\text { rates } \\
(\mathrm{g} / \mathrm{s})\end{array}$ \\
\hline $\mathrm{FL}$ & Truck loadout flare & Point & 6.1 & 1255 & 6 & 0.8 & 0.000073 \\
\hline EM & $\begin{array}{c}\text { Emergency fire } \\
\text { water pump }\end{array}$ & Point & 8.94 & 622 & 16.5 & 0.2 & 0.000015 \\
\hline $\mathrm{PL}$ & Product loading & Point & 6.1 & 1255 & 6 & 0.8 & 0.00052 \\
\hline $\mathrm{BF}$ & Biomethanator flare & Point & 6.7 & 1255 & 3 & 0.8 & 0.000047 \\
\hline ST4 & $\begin{array}{c}\text { Storage tanks } \\
\text { (denaturant) }\end{array}$ & Point & 11.9 & N/A & $\mathrm{N} / \mathrm{A}$ & N/A & 0.0097 \\
\hline ST5 & $\begin{array}{c}\text { Storage tanks } \\
\text { (denatured ethanol) }\end{array}$ & Point & 16.8 & N/A & N/A & N/A & 0.000086 \\
\hline ST6 & $\begin{array}{c}\text { Storage tanks } \\
\text { (denatured ethanol) }\end{array}$ & Point & 16.8 & N/A & N/A & N/A & 0.000086 \\
\hline
\end{tabular}

Base elevation $=75$

\subsection{Surface meteorological data}

In order to model the meteorological factors, days had to be chosen to represent different seasons so that the hourly readings of temperature $\left({ }^{\circ} \mathrm{C}\right)$, precipitation $(\mathrm{mm})$, relative humidity $(\%)$, wind vector direction $\left({ }^{\circ}\right)$, wind speed $(\mathrm{m} / \mathrm{s})$, and pressure (mbar) could be used for the modelling. The dates selected were, therefore, based on the availability of a complete set of data for the surface station and upper station. The surface meteorological data obtained, were 
taken from the official Government of Canada logs on climate (Government of Canada, 2013) from the closest weather station to the point of interest (POI), Toronto Pearson International Airport. To model winter conditions, surface meteorological data were taken from 09 January 2013 at $00 \mathrm{h00}$ Local Standard Time (LST) to 11 January 2013 at 23 h00 LST. The same range of dates and times were chosen for April to model spring and June to model summer. All the data gathered were then put into a specific format so that they were compatible with the SMERGE program, which would produce a SURF.DAT file to then be used with CALMET. A summary of the retrieved data is located in Table 2. SMERGE is a meteorological preprocessor which processes hourly surface observations from a number of stations in U.S. National Climatic Data Center (NCDC) CD-144 format or NCDC CD-ROM format and reformats the data into a single file with the data sorted by time rather than station. The CD-ROM format contains data in either the Solar and Meteorological Surface Observational Network (SAMSON) format or the Hourly U.S. Weather Observations (HUSWO) format. CALMET is a meteorological model which includes a diagnostic wind field generator containing objective analysis and parameterized treatments of slope flows, kinematic terrain effects, terrain blocking effects, and a divergence minimization procedure, and a micrometeorological model for overland and overwater boundary layers (Scire et al., 2000).

Table 2. Information about the surface station and upper air station that was used to obtain surface and upper air meteorological data

\begin{tabular}{cc}
\hline & Surface station \\
\hline Parameter & $\begin{array}{c}\text { Values } \\
\text { International Airport, Ontario, } \\
\text { Canada }\end{array}$ \\
\hline Station Name & $43.67722^{\circ} \mathrm{N}$ \\
\hline UTM Latitude & $79.63056^{\circ} \mathrm{W}$ \\
\hline UTM Longitude & $173.40 \mathrm{~m}$ \\
\hline Elevation & 6158733 \\
\hline Climate ID & 71624 \\
\hline WMO ID & YYZ \\
\hline TC ID & Values \\
\hline Parameter & Upper air station \\
\hline Station & Buffalo Airport, New York, USA \\
\hline Name/Location & $42.93^{\circ} \mathrm{N}$ \\
\hline UTM Latitude & $78.73^{\circ} \mathrm{W}$ \\
\hline UTM Longitude & $218 \mathrm{~m}$ \\
\hline Elevation & 14733 \\
\hline WBAN & 72528 \\
\hline WMO ID & $\mathrm{BUF}$ \\
\hline INIT & \\
\hline
\end{tabular}

\subsection{Upper air data}

Upper air meteorological data were acquired from the National Oceanic and Atmospheric Administration/Earth System Research Laboratory (NOAA/ESRL) radiosonde website (NOAA, 2013). The radiosonde station was selected based on its geographically similar location and upper air conditions experienced to the above-chosen surface station as well as how near it was to the point of interest (POI). Data were extracted from the yearly reports of upper air data for 2013 using the website's search engine. The data required for the modelling software, were taken on the same days as for the surface station. These days were selected on the basis of having full sets of data available for both $00 \mathrm{~h} 00$ and $23 \mathrm{~h} 00$ respectively and were in sets of three: January 9-11, 2013, April 9-11, 2013, and June 9-11, 2013. If for any reason necessary data were not included for the chosen days for either station which was kept as a controlled variable for each month, data for both the surface station and upper station for the days in question were omitted from use and new days corresponding to the winter, spring, and summer seasons were chosen until a fully complementary set of data was achieved for each required set of days. The extracted upper surface meteorological data were then converted into the form necessary for processing by the READ62 processor in CALMET. READ62 is a meteorological preprocessor which extracts and processes upper air wind and temperature data from the standard NCDC TD-6201 data format or the NCDC CD-ROM FSL rawinsonde (a method of upperatmosphere meteorological observation conducted by means of a radiosonde tracked by radar) data format (Scire et al., 2000). Table 2, which contains the Universal Transverse Mercator (UTM) latitude and longitude, elevation, WBAN (Weather Bureau Army Navy), WMO (World Meteorological Organization) ID, and INIT of the selected radiosonde station summarizes the upper meteorological data used for the model.

\subsection{Implementation of CALPUFF modelling system}

In this study, benzene concentration over a 24-hour period of exposure is simulated by the CALPUFF modelling system, CALPro software (CALPro Plus V6.9.10.25.2007). The simulation package consists of a pre-processing (CALMET), a simulation (CALPUFF), and a post-processing package (CALPOST/PRTMET) with their respective graphical user interfaces (Valdenebro et al., 2013). Before any package is used, a set of commonly shared information must be entered. The information relates to space-time data, such as the time zone, coordinate system, and layer data, so that meteorological information and geophysical information can be used within a standardized frame of reference, regardless of which processor is being used. A summary of the input shared common information is recorded in Table 3. Prior to running the CALPUFF pre-processors, shared information on the meteorological grid is entered into a common file using the Identify Shared Information module. The information is shared amongst all CALPUFF processors (Table 3). The domain of the grid was selected to be $30 \times$ $30 \mathrm{~km}^{2}$, where the center of the grid corresponds to the location of the proposed ethanol producing facility. Moreover, the Lambert Conformal Conic projection coordinate system is employed and all coordinates are defined in the North American Datum of 1983. 
Table 3. Model input information for the domain of study

\begin{tabular}{lc}
\hline Parameter & Values \\
\hline Projection & LCC (Lambert Conformal Conic) \\
\hline LCC latitude of origin & $43.866667^{\circ} \mathrm{N}$ \\
\hline LCC longitude of origin & $78.816667^{\circ} \mathrm{W}$ \\
\hline Latitude 1 & $10^{\circ} \mathrm{N}$ \\
\hline Latitude 2 & $50{ }^{\circ} \mathrm{N}$ \\
\hline False Easting & 0 \\
\hline False Northing & 0 \\
\hline Continent/Ocean & North America \\
\hline Geoid-Ellipsoid & North American Datum of 1983 (NAD83): GRS 80 \\
\hline Region & Canada \\
\hline DATUM code & $-30 \mathrm{~km}$ \\
\hline$X$ (Easting) & $-30 \mathrm{~km}$ \\
\hline Y (Northing) & 200 \\
\hline Number of X grid lines & 200 \\
\hline Number of Y grid lines & $150 \mathrm{~m}$ \\
\hline Grid spacing & 9 \\
\hline Number of vertical layers & American 1983, Canada) \\
\hline Cell face heights (m) & $0-20,20-50,50-100,100-150,150-200,200-300,300-500,500-1000,1000-2000$ \\
\hline Base time zone & Universal Time Coordinated (UTC)-05:00 Eastern time \\
\hline UTM zone & 17 \\
\hline Hemisphere & Northern \\
\hline
\end{tabular}

The coordinates (Figure 1) for the proposed site are provided through Google Earth, and the the seconds and minutes are converted into degrees by an online converter (Federal Communications Division, 2013). A Cartesian grid is required for CALMET, one of the pre-processors for CALPro with the reference in the lower left corner. Around the POI, the size of the region of study is set at $-30 \mathrm{~km}$ for each easting and northing as it sufficiently covers more than one urban/built-up most likely residential area on the land use map.

The CALPUFF modeling system uses a grid system consisting of an array of horizontal grid lines and multiple vertical layers. Two grids (meteorological and computational) must be defined in the CALPUFF model. The meteorological grid defines the extent over which land is used, also winds, and other meteorological variables. The computational grid defines the extent of the concentration calculations (US EPA, 1998). The solution grid consists of many small segments that make up the entire volume of the simulation domain. These segments may be different shapes depending on the geometry of the problem being modeled. In order to obtain a solution that best corresponds to reality, it is necessary to obtain "grid independence", which equates to having enough grids to properly resolve the relevant details of the field (Sohn et al., 2004). In this study, within the defined area of study, a maximum of 200 gridlines are allowed by CALPro to ensure that the most detailed analysis possible is carried out for individual segments. Grid spacing was required as input into the shared common information, but was easily calculated by using the $30 \mathrm{~km}$ in each axis divided by 200 grid lines to get a grid spacing of $150 \mathrm{~m}$. The input of a base time zone is considered to be UTC-05:00 (for Oshawa, Canada) in CALPro.

Since the area of study has a coastline that will affect dispersion, coastline data (gshhs_1.3.zip) had to be individually added to the North America land use data and terrain data typically required to eventually create a GEO.DAT file to be used in CALMET. All the relevant coastline, land use, and terrain data can be found in the Atmospheric Studies Groups (2013). The LU.DAT file for land use was created by using the coastline and land use data together in the CTGPROC.INP. Similarly, the TERREL.DAT file for the terrain can be obtained by using the coastline data and the raw terrain data files with the TERREL.INP pre-processor. Combining the LU.DAT and the TERREL.DAT in the MAKEGEO.INP processor yields a GEO.DAT file, which was used in CALMET with the individual SURF.DAT file and UPPER.DAT file for January, April, and June. This information was used to create three CALMET.DAT files which can be used to show the wind vectors in the terrain maps. In order to model the dispersion, the three CALPUFF.DAT files were created with the three existing CALMET.DAT files using the CALPUFF.INP processor. For a written .LST file in which all the benzene concentrations were logged, CALPOST was used with the CALPUFF data files for January, April, and June. The abovementioned computational procedure for running the CALPUFF modelling system is depicted in Figure 3. 


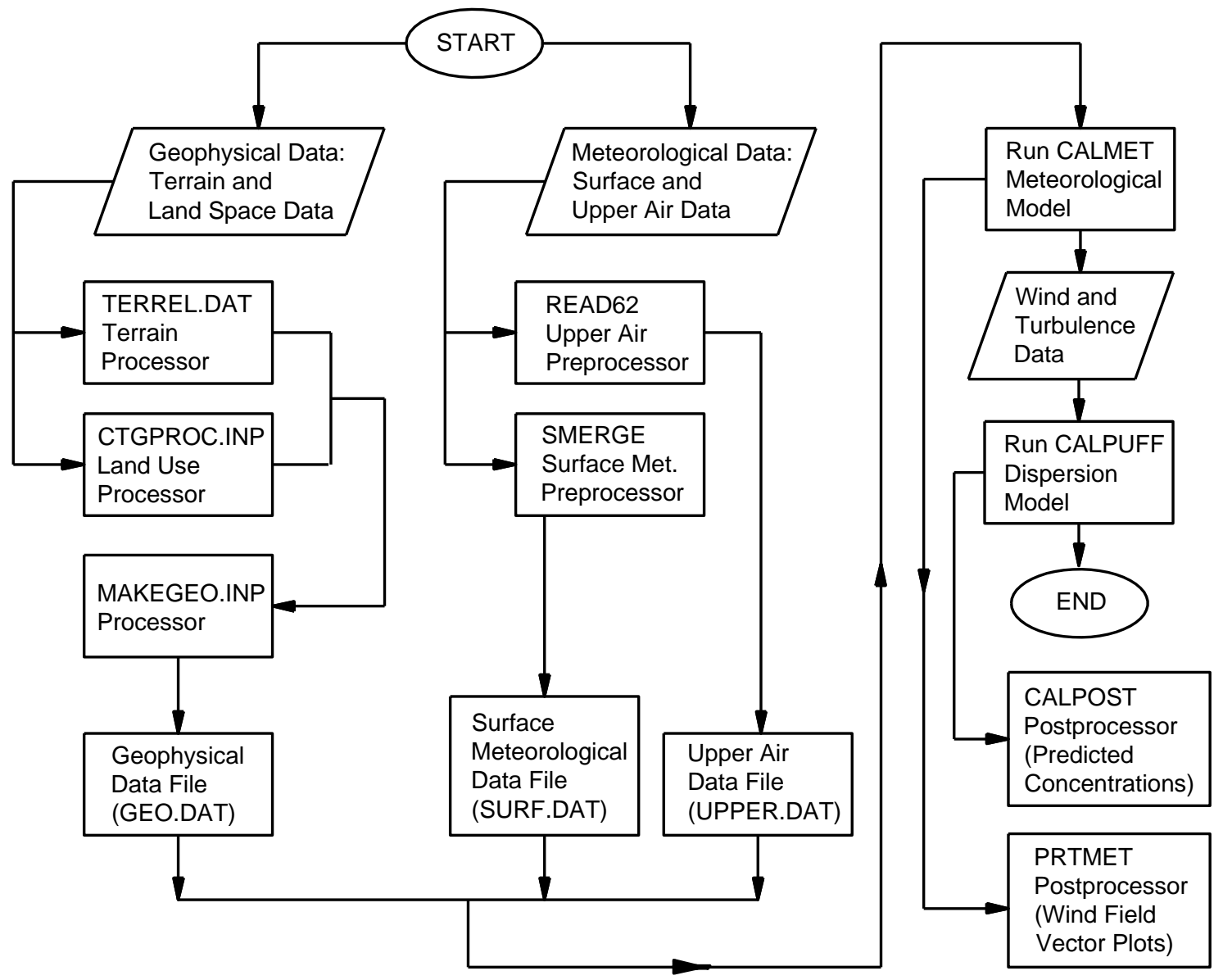

Figure 3. Process flow diagram of the CALPUFF modelling system

In the CALPUFF modeling system, each of the three programs (CALMET, CALPUFF, and CALPOST) uses a control file of user-selectable options to control the data processing. The following values for miscellaneous dispersion and computational parameters (group 12) were set as follows: EPSSLUG (fractional convergence criterion for numerical SLUG sampling integration) $=1.0 \mathrm{e}-04$, and EPSAREA (fractional convergence criterion for numerical AREA source integration) $=1.0 \mathrm{e}-06$.

CALPUFF is a non-steady-state Lagrangian puff model (i.e., non-steady-state emissions and meteorological conditions). It is a non-steady state puff dispersion model that can simulate the effects of time and space varying meteorological conditions on pollutant transport, transformation, and removal. The model allows two puff sampling functions to be selected (i.e., slug sampling function and integrated puff function). For near field applications, a slug sampling function is used. During less demanding conditions, the integrated puff approached is used. Both functions create uninterrupted plume effects exactly under the proper steady state conditions. Details about the governing equations of the model under various conditions can be found in Scire et al. (2000).

\section{Results and discussions}

Three-season dispersion results for benzene are examined in this paper for a proposed ethanol-producing facility in Oshawa, Ontario. Three dates (January 10, 2013, April 10, 2013, and June 10, 2013) are chosen to simulate the external conditions of winter, spring, and summer, respectively. Also, their relevant effects on benzene dispersion is studied. The terrain of the proposed location is low-lying agricultural grade lands; however, the location is close to the coastline (Figures 1 and 2). Each day is analyzed between the hours of 00h00 to $23 \mathrm{~h} 00$ LST on an hourly basis and on a 24-hour basis. In order to obtain comparable values with the half-hour standard set by Ontario's Ministry of Environment, the hourly recorded concentrations are converted to a half-hour records using the following equation (Abdul-Wahab et al., 2016):

$$
\begin{aligned}
& \text { (Half-hour concentration) }=(\text { One-hour } \\
& \text { concentration) } \times(1 \mathrm{~h} / 0.5 \mathrm{~h})^{0.28}
\end{aligned}
$$

In January 10, 2013, the single most influential external factor of benzene dispersion was the wind vector. The wind vector influences both the magnitude and direction of the benzene dispersal, by gradually changing from southerly to northerly. The in-depth analysis of the causes of significant dissemination of the benzene is related to the wind vectors (Figure 4). The wind direction and speed vary over the measured period along, causing a wide dispersion of the pollutant over the domain. Of particular interest are the days with the highest and second highest recorded concentration levels at $17 \mathrm{~h} 00$ and $19 \mathrm{h00}$ LST (Figure 5). As it is presented in Table 4, the highest concentration occurred at $17 \mathrm{~h} 00$ LST at grid coordinates $0.150 \mathrm{~km}$ west and $0.450 \mathrm{~km}$ north from the POI. The concentration measured at this point is $4.585 \mu \mathrm{g} / \mathrm{m}^{3}$. The second highest 
concentration measured is $2.948 \mu \mathrm{g} / \mathrm{m}^{3}$ at coordinates $0.450 \mathrm{~km}$ west and $0.150 \mathrm{~km}$ north of the POI at time $19 \mathrm{h00}$ LST (Table 4).

To represent spring season, pollution dispersion on April 10, 2013, has been examined. The dissemination of benzene vapours from the POI was towards the southwest (Figure 5) as the wind vectors remained in this general direction throughout the time period examined. The two highest values for the day are recorded at $21 \mathrm{~h} 00$ and $07 \mathrm{~h} 00$ LST. These concentrations are $1.345 \mu \mathrm{g} / \mathrm{m}^{3}$ and 0.866 $\mu \mathrm{g} / \mathrm{m}^{3}$, respectively (Table 5 ).

Table 4. List of the top 20 one-hour and 24-hour average $\mathrm{C}_{6} \mathrm{H}_{6}$ concentrations simulated on January 10, 2013 from $00 \mathrm{~h} 00$ to $23 \mathrm{~h} 00$

\begin{tabular}{|c|c|c|c|c|c|}
\hline \multirow[b]{2}{*}{ No. } & \multicolumn{3}{|c|}{ One-hour average $\mathrm{C}_{6} \mathrm{H}_{6}$ concentrations } & \multicolumn{2}{|c|}{ 24-hour average $\mathrm{C}_{6} \mathrm{H}_{6}$ concentrations } \\
\hline & $\begin{array}{c}\text { Time } \\
\text { (HH:MM) }\end{array}$ & $\begin{array}{c}\text { Concentration } \\
\left(\mu \mathrm{g} / \mathrm{m}^{3}\right)\end{array}$ & $\begin{array}{c}\text { Coordinates } \\
(\mathbf{k m})\end{array}$ & $\begin{array}{c}\text { Concentration } \\
\left(\mu \mathrm{g} / \mathrm{m}^{3}\right)\end{array}$ & $\begin{array}{c}\text { Coordinates } \\
(\mathrm{km})\end{array}$ \\
\hline 1 & $17: 00$ & 4.585 & $-0.150,0.450$ & 0.403 & $-0.150,0.450$ \\
\hline 2 & 19:00 & 2.948 & $-0.450,0.150$ & 0.233 & $-0.150,0.150$ \\
\hline 3 & 13:00 & 2.369 & $0.150,0.450$ & 0.130 & $0.150,-0.450$ \\
\hline 4 & $15: 00$ & 1.884 & $-0.150,0.150$ & 0.193 & $-0.450,0.150$ \\
\hline 5 & $18: 00$ & 1.848 & $-0.150,0.150$ & 0.110 & $-0.750,0.450$ \\
\hline 6 & $14: 00$ & 1.274 & $-1.350,0.450$ & 0.103 & $-1.350,0.750$ \\
\hline 7 & $19: 00$ & 1.230 & $-1.350,0.450$ & 0.087 & $-0.450,0.450$ \\
\hline 8 & $20: 00$ & 1.224 & $-0.745,0.450$ & 0.080 & $-1.350,0.450$ \\
\hline 9 & $17: 00$ & 1.208 & $-0.450,1.350$ & 0.075 & $0.150,-0.150$ \\
\hline 10 & $22: 00$ & 1.204 & $-0.450,0.150$ & 0.072 & $0.750,0.450$ \\
\hline 11 & $21: 00$ & 1.126 & $-0.750,0.450$ & 0.063 & $-0.450,1.350$ \\
\hline 12 & $20: 00$ & 1.113 & $-1.350,0.750$ & 0.057 & $0.750,-0.450$ \\
\hline 13 & $21: 00$ & 1.098 & $-1.350,0.750$ & 0.056 & $0.450,0.150$ \\
\hline 14 & $18: 00$ & 0.915 & $-0.450,0.450$ & 0.054 & $1.350,0.750$ \\
\hline 15 & $16: 00$ & 0.790 & $-0.150,0.450$ & 0.047 & $-1.050,1.350$ \\
\hline 16 & 06:00 & 0.764 & $0.450,0.150$ & 0.046 & $-1.050,0.450$ \\
\hline 17 & $18: 00$ & 0.752 & $-1.050,1.350$ & 0.044 & $1.950,1.050$ \\
\hline 18 & 01:00 & 0.711 & $0.150,-0.150$ & 0.042 & $-1.950,0.750$ \\
\hline 19 & $18: 00$ & 0.689 & $-1.350,1.650$ & 0.042 & $-1.350,1.650$ \\
\hline 20 & $07: 00$ & 0.682 & $0.750,0.150$ & 0.040 & $0.150,-0.750$ \\
\hline
\end{tabular}

Table 5. List of the top 20 one-hour and 24-hour average $\mathrm{C}_{6} \mathrm{H}_{6}$ concentrations simulated on April 10, 2013 from 00 h00 to $23 \mathrm{~h} 00$

\begin{tabular}{|c|c|c|c|c|c|}
\hline \multirow[b]{2}{*}{ No. } & \multicolumn{3}{|c|}{ One-hour average $\mathrm{C}_{6} \mathrm{H}_{6}$ concentrations } & \multicolumn{2}{|c|}{ 24-hour average $\mathrm{C}_{6} \mathrm{H}_{6}$ concentrations } \\
\hline & $\begin{array}{c}\text { Time } \\
\text { (HH:MM) }\end{array}$ & $\begin{array}{c}\text { Concentration } \\
\left(\mu \mathrm{g} / \mathrm{m}^{3}\right)\end{array}$ & $\begin{array}{c}\text { Coordinates } \\
(\mathrm{km})\end{array}$ & $\begin{array}{c}\text { Concentration } \\
\left(\mu \mathrm{g} / \mathrm{m}^{3}\right)\end{array}$ & $\begin{array}{c}\text { Coordinates } \\
(\mathbf{k m})\end{array}$ \\
\hline 1 & $21: 00$ & 1.345 & $-0.150,0.450$ & 0.136 & $-0.150,-0.450$ \\
\hline 2 & 07:00 & 0.866 & $-0.150,0.150$ & 0.104 & $-0.150,-0.150$ \\
\hline 3 & $22: 00$ & 0.854 & $-0.450,-0.750$ & 0.069 & $0.150,-0.750$ \\
\hline 4 & $20: 00$ & 0.748 & $-0.150,-0.450$ & 0.056 & $0.150,-1.050$ \\
\hline 5 & $10: 00$ & 0.600 & $-0.150,-0.150$ & 0.048 & $-0.150,-0.750$ \\
\hline 6 & 08:00 & 0.467 & $-0.150,-0.750$ & 0.042 & $0.150,-1.350$ \\
\hline 7 & $11: 00$ & 0.452 & $-0.150,-0.150$ & 0.042 & $-0.450,-0.750$ \\
\hline 8 & 00:00 & 0.433 & $0.150,-0.750$ & 0.041 & $-0.150,-1.050$ \\
\hline 9 & $14: 00$ & 0.376 & $-0.150,-0.450$ & 0.038 & $-0.150,-1.350$ \\
\hline 10 & 08:00 & 0.372 & $-0.150,-0.450$ & 0.035 & $-0.450,-1.050$ \\
\hline 11 & $18: 00$ & 0.354 & $0.150,-0.750$ & 0.034 & $-0.150,-1.650$ \\
\hline 12 & $22: 00$ & 0.340 & $-0.750,-1.350$ & 0.033 & $0.150,-1.650$ \\
\hline 13 & $16: 00$ & 0.316 & $0.150,-0.750$ & 0.032 & $0.150,-0.450$ \\
\hline 14 & 06:00 & 0.306 & $0.150,-0.750$ & 0.031 & $-0.150,-1.950$ \\
\hline 15 & $21: 00$ & 0.301 & $-0.450,-1.050$ & 0.028 & $-0.150,-2.250$ \\
\hline 16 & $00: 00$ & 0.283 & $0.150,-1.050$ & 0.027 & $0.150,-1.950$ \\
\hline 17 & 08:00 & 0.277 & $-0.150,-1.050$ & 0.027 & $-0.450,-1.350$ \\
\hline 18 & 07:00 & 0.261 & $-0.450,-0.450$ & 0.025 & $-0.150,-2.550$ \\
\hline 19 & $15: 00$ & 0.249 & $-0.150,-0.750$ & 0.022 & $0.150,-2.250$ \\
\hline 20 & $21: 00$ & 0.246 & $-0.450,-1.350$ & 0.022 & $-0.150,-2.850$ \\
\hline
\end{tabular}


They are calculated at grid locations $0.150 \mathrm{~km}$ west and $0.450 \mathrm{~km}$ north, and at $0.150 \mathrm{~km}$ west and $0.150 \mathrm{~km}$ north of the POI. It is noted that both locations are expressed as places relative to the study's POI. Referring to the terrain map in Figure 2, and the wind rose diagram presented in Figure 4, the reason of uniform teardrop-shaped distribution of the pollutant dispersion graphic is found in Figure 5. The fairly steady wind speeds, which ranging primarily from $3.3-5.4 \mathrm{~m} / \mathrm{s}$, combined with the low-lying terrain and lack of land dispersion factors in a mostly uniform area accounted for this behavior.

June 10, 2013 represents the summer season in this study. The wind (speed ranging between 0.5 and $5.4 \mathrm{~m} / \mathrm{s}$ ) mostly

Table 6. List of the top 20 one-hour and 24-hour average $\mathrm{C}_{6} \mathrm{H}_{6}$ concentrations simulated on June 10, 2013 from $00 \mathrm{~h} 00$ to $23 \mathrm{~h} 00$

\begin{tabular}{|c|c|c|c|c|c|}
\hline \multirow[b]{2}{*}{ No. } & \multicolumn{3}{|c|}{ One-hour average $\mathrm{C}_{6} \mathrm{H}_{6}$ concentrations } & \multicolumn{2}{|c|}{ 24-hour average $\mathrm{C}_{6} \mathrm{H}_{6}$ concentrations } \\
\hline & $\begin{array}{c}\text { Time } \\
\text { (HH:MM) }\end{array}$ & $\begin{array}{c}\text { Concentration } \\
\left(\mu \mathrm{g} / \mathrm{m}^{3}\right)\end{array}$ & $\begin{array}{c}\text { Coordinates } \\
(\mathbf{k m})\end{array}$ & $\begin{array}{c}\text { Concentration } \\
\left(\mu \mathrm{g} / \mathrm{m}^{3}\right)\end{array}$ & $\begin{array}{c}\text { Coordinates } \\
(\mathrm{km})\end{array}$ \\
\hline 1 & $01: 00$ & 1.085 & $-0.750,-0.450$ & 0.277 & $-0.450,-0.150$ \\
\hline 2 & $22: 00$ & 0.854 & $-0.450,-0.750$ & 0.139 & $-0.150,-0.150$ \\
\hline 3 & 00:00 & 0.825 & $-0.750,-0.450$ & 0.131 & $-0.750,-0.450$ \\
\hline 4 & $02: 00$ & 0.823 & $-0.450,-0.150$ & 0.090 & $-1.050,-0.450$ \\
\hline 5 & 07:00 & 0.810 & $-0.150,-0.150$ & 0.088 & $-0.750,-0.150$ \\
\hline 6 & 08:00 & 0.810 & $-0.150,-0.150$ & 0.075 & $-1.350,-0.450$ \\
\hline 7 & 09:00 & 0.809 & $-0.150,-0.150$ & 0.053 & $-1.350,-0.150$ \\
\hline 8 & 05:00 & 0.805 & $-0.450,-0.150$ & 0.042 & $-1.050,-0.150$ \\
\hline 9 & 03:00 & 0.748 & $-0.450,-0.150$ & 0.041 & $-1.950,-0.750$ \\
\hline 10 & $20: 00$ & 0.678 & $-0.450,-0.150$ & 0.041 & $-0.450,-0.750$ \\
\hline 11 & 04:00 & 0.621 & $-0.750,-0.150$ & 0.035 & $-2.250,-0.750$ \\
\hline 12 & $19: 00$ & 0.590 & $-0.450,-0.150$ & 0.033 & $-1.650,-0.450$ \\
\hline 13 & $16: 00$ & 0.522 & $-0.450,-0.150$ & 0.033 & $-1.650,-0.750$ \\
\hline 14 & 02:00 & 0.443 & $-1.050,-0.450$ & 0.027 & $-1.950,-1.050$ \\
\hline 15 & $21: 00$ & 0.408 & $-0.750,-0.450$ & 0.027 & $-1.050,-0.750$ \\
\hline 16 & 01:00 & 0.405 & $-1.350,-0.750$ & 0.027 & $-1.650,-1.050$ \\
\hline 17 & $02: 00$ & 0.377 & $-1.350,-0.450$ & 0.027 & $-2.850,-1.050$ \\
\hline 18 & 04:00 & 0.332 & $-1.050,-0.150$ & 0.025 & $-0.450,-0.450$ \\
\hline 19 & 03:00 & 0.323 & $-1.050,-0.450$ & 0.023 & $-2.550,-1.050$ \\
\hline 20 & $22: 00$ & 0.318 & $-0.750,-1.350$ & 0.021 & $-3.150,-1.050$ \\
\hline
\end{tabular}

Table 7 shows the top 20 (one-hour, half-hour, and 24hour) modelled concentrations for benzene dispersion. The results indicate none of the months exceed the half-hour limit of $7 \mu \mathrm{g} / \mathrm{m}^{3}$ set by Ontario Regulation 419/05; however, all the top 20 concentrations for each modelled month exceed the Ontario Regulation 419 Schedule 3 limit of $0.01 \mathrm{\mu g} / \mathrm{m}^{3}$ for a 24 -hour dispersion period. These concentrations reach up to $0.242 \mu \mathrm{g} / \mathrm{m}^{3}$ (240\%), which is significantly higher than the regulatory amount. Although these values are lower than the referenced AERMOD values from the previous emission model $\left(0.8 \mathrm{\mu g} / \mathrm{m}^{3}\right)$, a direct comparison cannot be drawn because different days could have been modelled; hence, different meteorological attributes could have influenced benzene dispersion. On the other hand, since these are representative months, one can say that the values can compare to some extent; however, even if that is the case, the concentrations of benzene still exceeded the 24-hour limit.

\section{Conclusions}

originated in the south and west (Figure 4). The peak concentration for benzene on an hourly basis of analysis was at $01 \mathrm{~h} 00$ LST when the benzene concentration reached $1.085 \mu \mathrm{g} / \mathrm{m}^{3}$ at $0.750 \mathrm{~km}$ west and $0.450 \mathrm{~km}$ south of the origin (Table 6). The corresponding maximum concentration of benzene on a 24-hour average is found to be $0.277 \mu \mathrm{g} / \mathrm{m}^{3}$ at a location $0.450 \mathrm{~km}$ west and $0.150 \mathrm{~km}$ south from the POI (Table 6). Further analysis of these particular instances in time reveals that the plume trajectory is towards the southeast, and once again passed over Lake Ontario. 
affecting humans as much as in January, when constantly changing wind vectors caused a large dispersion of benzene vapour. These results, coupled with the fact that the majority of the measured data surpassed the guideline limit values set by the government, suggest that emissions from the proposed facility could lead to undesirable effects on humans and plant life
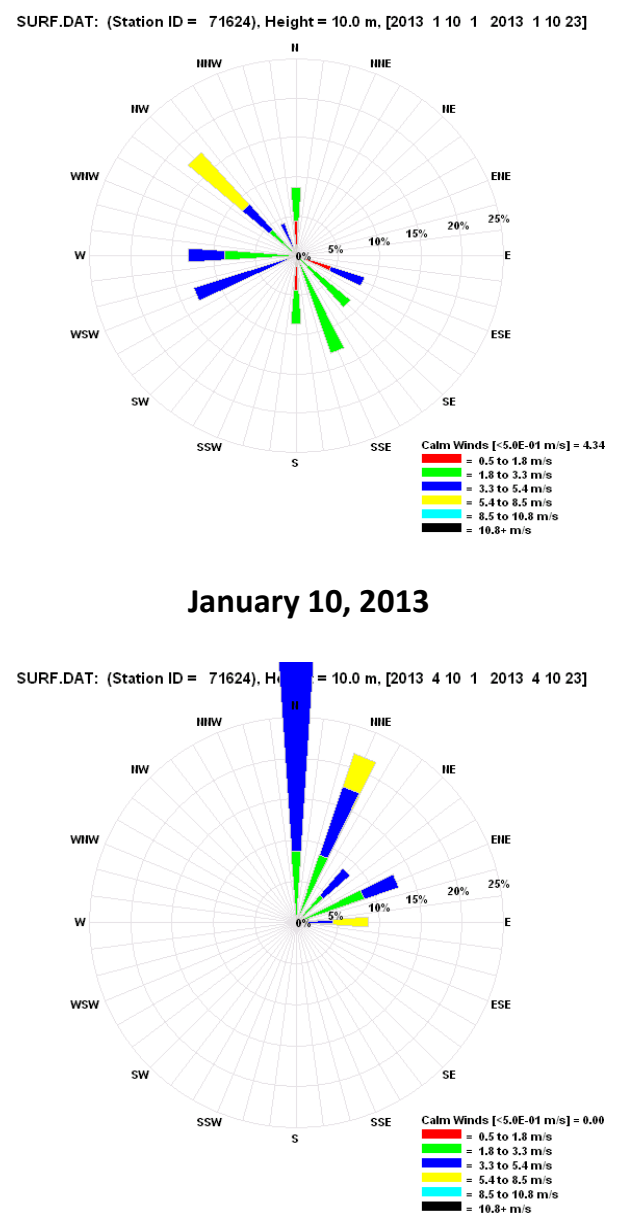

April 10, 2013

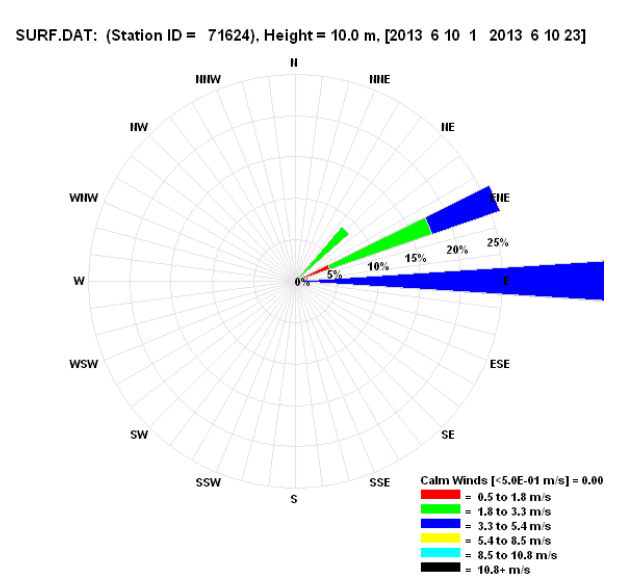

June 10, 2013

Figure 4. Wind rose diagrams for January 10, 2013, April 10, 2013, and June 10, 2013 
Jan 10, 2013

17:00 LST(UTC-0500) Wind, Conc (ug/m**3)

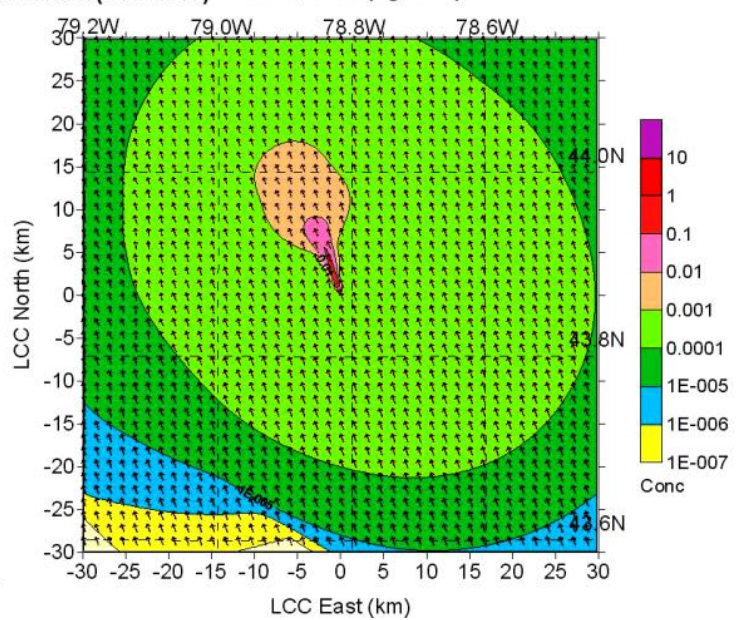

Jan 10, 2013

19:00 LST(UTC-0500) Wind, Conc (ug $/ \mathrm{m}^{\star * 3}$ )

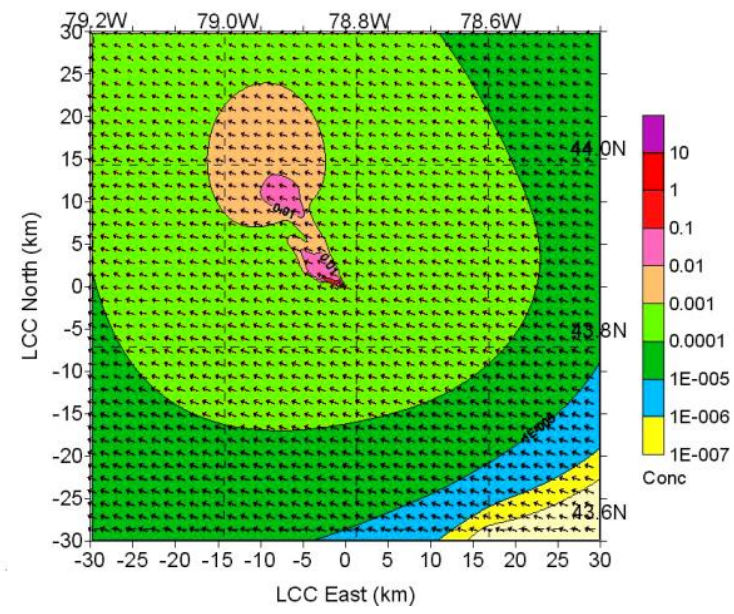

January 10, 2013
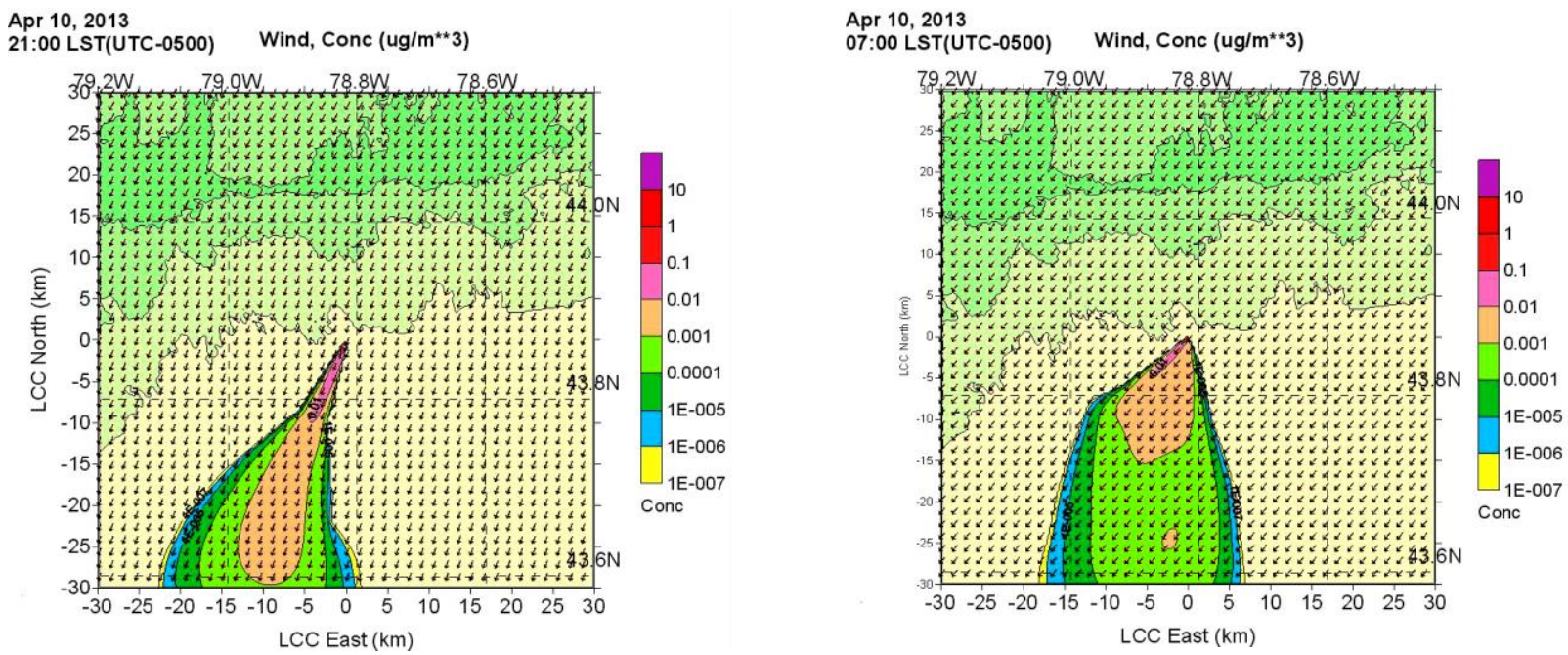

April 10, 2013

Jun 10, 2013
01:00 LST(UTC-0500) Wind, Conc (ug/m**3)
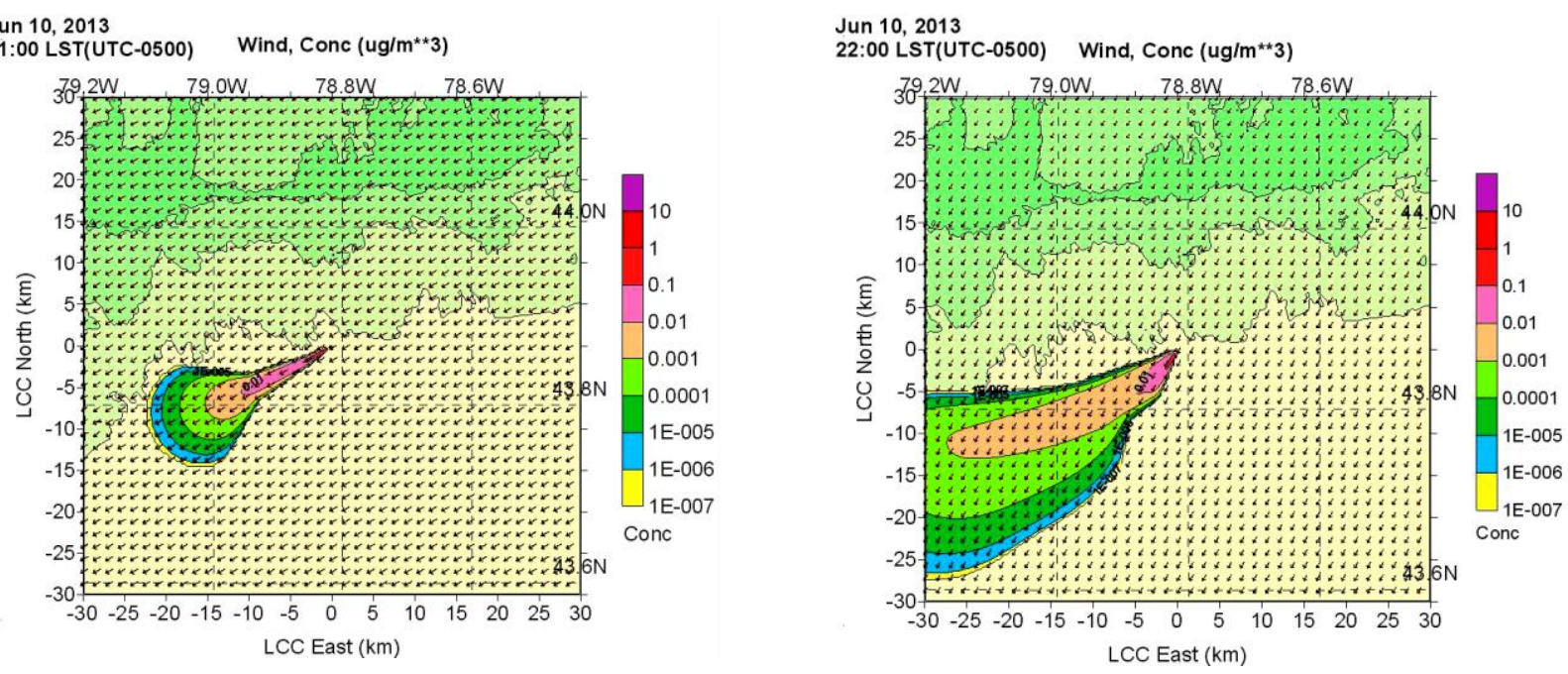

June 10, 2013

Figure 5. Dispersion results for January 10, 2013, April 10, 2013 and June 10, 2013 
Table 7. Top 20 modelled one-hour, half-hour, and 24-hour concentrations of $\mathrm{C}_{6} \mathrm{H}_{6}$

\begin{tabular}{ccccccccc}
\hline & January & & \multicolumn{3}{c}{ April } & & \multicolumn{3}{c}{ June } \\
\hline One-hour & Half-hour & $\mathbf{2 4 - h o u r}$ & One-hour & Half-hour & 24-hour & One-hour & Half-hour & 24-hour \\
\hline 4.585 & 5.567 & 0.242 & 1.345 & 1.633 & 0.136 & 1.085 & 1.317 & 0.277 \\
\hline 2.948 & 3.580 & 0.233 & 0.866 & 1.051 & 0.104 & 0.854 & 1.037 & 0.140 \\
\hline 2.369 & 2.876 & 0.193 & 0.854 & 1.037 & 0.069 & 0.825 & 1.002 & 0.131 \\
\hline 1.884 & 2.288 & 0.130 & 0.748 & 0.908 & 0.056 & 0.823 & 0.999 & 0.090 \\
\hline 1.848 & 2.243 & 0.110 & 0.600 & 0.729 & 0.048 & 0.810 & 0.984 & 0.088 \\
\hline 1.274 & 1.547 & 0.103 & 0.467 & 0.567 & 0.042 & 0.810 & 0.983 & 0.075 \\
\hline 1.230 & 1.493 & 0.087 & 0.452 & 0.549 & 0.042 & 0.809 & 0.983 & 0.053 \\
\hline 1.224 & 1.486 & 0.080 & 0.452 & 0.548 & 0.041 & 0.805 & 0.978 & 0.042 \\
\hline 1.208 & 1.467 & 0.075 & 0.433 & 0.526 & 0.038 & 0.748 & 0.909 & 0.041 \\
\hline 1.204 & 1.462 & 0.072 & 0.376 & 0.457 & 0.035 & 0.678 & 0.823 & 0.041 \\
\hline 1.126 & 1.367 & 0.063 & 0.372 & 0.452 & 0.034 & 0.621 & 0.754 & 0.035 \\
\hline 1.113 & 1.351 & 0.057 & 0.351 & 0.427 & 0.033 & 0.590 & 0.716 & 0.033 \\
\hline 1.098 & 1.333 & 0.056 & 0.340 & 0.413 & 0.032 & 0.522 & 0.634 & 0.033 \\
\hline 0.952 & 1.155 & 0.054 & 0.316 & 0.384 & 0.031 & 0.443 & 0.538 & 0.027 \\
\hline 0.791 & 0.95985 & 0.047 & 0.306 & 0.372 & 0.028 & 0.408 & 0.496 & 0.027 \\
\hline 0.764 & 0.928 & 0.046 & 0.301 & 0.366 & 0.027 & 0.405 & 0.492 & 0.027 \\
\hline 0.752 & 0.913 & 0.044 & 0.283 & 0.344 & 0.027 & 0.377 & 0.457 & 0.027 \\
\hline 0.711 & 0.864 & 0.042 & 0.277 & 0.336 & 0.026 & 0.332 & 0.403 & 0.025 \\
\hline 0.689 & 0.836 & 0.042 & 0.26057 & 0.316 & 0.025 & 0.323 & 0.392 & 0.023 \\
\hline 0.682 & 0.828 & 0.040 & 0.24883 & 0.302 & 0.022 & 0.318 & 0.386 & 0.021 \\
\hline & & & & & & & &
\end{tabular}

\section{References}

Abdul-Wahab S., Sappurd A. and Al-Damkhi A. (2011), Application of California Puff (CALPUFF) model: a case study for Oman, Clean Technologies and Environmental Policy, 13(1), 177-189.

Abdul-Wahab S.A., Lohi A., Yetilmezsoy K., Elkamel A. and Chan K. (2014), Modeling of formaldehyde and nitrogen oxides from a proposed renewable energy biogas facility in Canada, Journal of Renewable and Sustainable Energy, 6(4), 043121.

Abdul-Wahab S.A., Ahmadi L., Elkamel A., Chan K., Yazdanpanah P. and Yetilmezsoy K. (2015), Study of the dispersion of $\mathrm{PM}_{10}$ in Canada, Fresenius Environmental Bulletin, 24(10a), 3320-3328.

Abdul-Wahab S.A., Ikhile E., En S.C.F., Elkamel A., Ahmadi L. and Yetilmezsoy K. (2016), Modeling the dispersion of $\mathrm{NO}_{\mathrm{x}}$ and $\mathrm{SO}_{2}$ emissions from a proposed biogas producing facility, Global Nest Journal, 18(4), 674-689.

Agriculture and Agri-Food Canada (2012), Public Participation Report Proposed FarmTech Ethanol Facility, Oshawa, Ontario, http://www.portofoshawa.ca/images/docs/publicparticipation-report-proposed-farmtech-ethanol-facility.pdf. Accessed in June 2017.

Alexopoulos E.C. and Bakeas E.B. (2011), Benzene: Environmental exposure, Encyclopedia of Environmental Health, 286-292.

Benigni R., Bossa C., Battistelli C.L. and Tcheremenskaia O. (2013), IARC Classes 1 and 2 carcinogens are successfully identified by an alternative strategy that detects DNA-reactivity and cell transformation ability of chemicals, Mutation Research/Genetic Toxicology and Environmental Mutagenesis, 758(1), 56-61.

Boobis A., Flari V., Gosling J.P., Hart A., Craig P., Rushton L. and Idahosa-Taylor E. (2013), Interpretation of the margin of exposure for genotoxic carcinogens-Elicitation of expert knowledge about the form of the dose response curve at human relevant exposures, Food and Chemical Toxicology, 57, 106-118.

Cohen J., Cook R., Bailey C.R. and Carr E. (2005), Relationship between motor vehicle emissions of hazardous pollutants, roadway proximity, and ambient concentrations in Portland, Oregon, Environmental Modelling and Software, 20(1), 7-12.

Ellenhorn J., Schonwald S., Ordog G. and Wasserberger J. (1997), Ellenhorn's Medical Toxicology: Diagnosis and Treatment of Human Poisoning. 2nd ed. Baltimore, MD: Williams and Wilkins, 1494.

Federal Communications Division (2013), Degrees, Minutes, Seconds and Decimal Degrees Latitude/Longitude Conversions,

http://transition.fcc.gov/mb/audio/bickel/DDDMMSSdecimal.html. Accessed in December 2015.

Government of Canada (2013), Historical Climate data, Climate, http://climate.weather.gc.ca/. Accessed in December 2015.

Government of Ontario (2013), Environmental Protection Act, Ontario Regulation 419/05: Air Pollution - Local Air Quality, Service Ontario, http://www.elaws.gov.on.ca/html/regs/english/elaws_regs_050419_e.ht m. Accessed in December 2015.

Holmes N.S. and Morawska L. (2006), A review of dispersion modelling and its application to the dispersion of particles: An overview of different dispersion models available, Atmospheric Environment, 40(30), 5902-5928.

Holnicki P., Kałuszko A. and Trapp W. (2016), An urban scale application and validation of the CALPUFF model, Atmospheric Pollution Research, 7(3), 393-402.

NOAA (National Oceanic and Atmospheric Administration) (2013), NOAA/ESRL Radiosonde Database, http://www.esrl.noaa.gov/raobs/. Accessed in December 2015.

Oshawa's Economic Development Services (2012), Development Inside: 2012 Oshawa's Diversity Comes into Focus, 
http://www.oshawa.ca/documents/DevelopmentInsider_20 12.pdf, Accessed in December 2015.

Scire J.S., Strimaitis D.G. and Yamartino R.J. (2000), A User's Guide for the CALPUFF Dispersion Model (Version 5), Earth Tech, Inc., Concord, MA 01742, www.src.com/calpuff/download/CALPUFF_UsersGuide.pdf. Accessed in March 2017.

Sohn C.W., Solberg A., Gonsoulin T. (2004), Analysis of numerical models for dispersion of chemical/biological agents in complex building environments, No. ERDC/CERL-TR-04-25, US Army Corps of Engineers, Engineer Research and Development Center, Washington, DC, US.

Statistics Canada (2012), Focus on Geograph Series 2011 Census, https://www12.statcan.gc.ca/census-recensement/2011/assa/fogs-spg/Facts-cma-

eng.cfm?LANG=Eng\&GK=CMA\&GC=532. Accessed in December 2015.

The Atmospheric Studies Group (2013), The CALPUFF Modelling System, http://www.src.com/calpuff/calpuff1.htm. Accessed in December 2015.

The City of Oshawa (2012), A brief history of the city of Oshawa, http://www.oshawa.ca/tourism/history3.asp. Accessed in December 2015.

US EPA (1998), A comparison of CALPUFF modeling results to two tracer field experiments, No. EPA-454/R-98-009, US Environmental Protection Agency Office of Air Quality Planning and Standards Emissions, Monitoring, and Analysis Division Research Triangle Park, NC, US.

Valdenebro V., Sáez de Cámara E., Gangoiti G., Alonso L., García J.A., Ilardia J.L. and González N. (2013), Evaluations of benzene impacts of a coke plant in a complex-topography urban area with the RAMS-CALMET-CALPUFF modelling system, WIT Transactions on Ecology and the Environment, 174, 39-45. 